\title{
Reinforcement Data for Fire Safety Design
}

\author{
Hertz, Kristian Dahl
}

Published in:

Magazine of Concrete Research

Publication date:

2004

Document Version

Version created as part of publication process; publisher's layout; not normally made publicly available

Link back to DTU Orbit

Citation (APA):

Hertz, K. D. (2004). Reinforcement Data for Fire Safety Design. Magazine of Concrete Research, 56(8), 453459.

\section{General rights}

Copyright and moral rights for the publications made accessible in the public portal are retained by the authors and/or other copyright owners and it is a condition of accessing publications that users recognise and abide by the legal requirements associated with these rights.

- Users may download and print one copy of any publication from the public portal for the purpose of private study or research.

- You may not further distribute the material or use it for any profit-making activity or commercial gain

- You may freely distribute the URL identifying the publication in the public portal

If you believe that this document breaches copyright please contact us providing details, and we will remove access to the work immediately and investigate your claim 


\title{
Reinforcement data for fire safety design
}

\author{
K.D.Hertz \\ Department of Civil Engineering, \\ Brovej Building 118, \\ Technical University of Denmark, \\ DK-2800 Kgs. Lyngby
}

\begin{abstract}
Idealized materials data are derived from a number of test series reported in the literature and made by the author. The data cover a variety of reinforcing steels from mild steel, deformed bars and cold-worked bars to cold-drawn prestressing steels. Processes are described that are responsible for the deterioration of the materials when they are heated and cooled down.

A simple expression is established for the description of deterioration curves for fireexposed materials such as concrete and reinforcement by means of five parameters that may be used as input data for structural fire safety calculations instead of the more troublesome application of curves or tables. This new idealized representation is compared with test data and with other idealized curves for the materials presented, and recommended design values are given.

Warnings are given for misleading curves and expressions from the structural codes. The paper serves as a basis for a number of papers presenting calculation methods developed by the author for the loadbearing capacity of constructions of any concrete at any time of any fire exposure.

Some of these methods and materials data are adopted in the CEN code and national codes such as the Danish DS411. The paper serves as a part of the documentation for the methods and is therefore also a supporting document for these standards.
\end{abstract}

Keywords: Fire safety design, Materials data, Reinforcement, Concrete structures 
Magazine of Concrete Research

\section{Introduction}

As a consulting engineer the author has felt a need for a rational basis for fire safety design of concrete structures. This subject has therefore been a main area of his research for 25 years, leading to a system of methods for design of beams, slabs, columns, walls and analyses of anchorage and spalling based on a continuous material research programme and supplemented with full-scale tests for verification of the design methods. This work will be documented in a series of papers mainly intended for MCR, where the present deals with basic idealised materials data for reinforcement, except the anchorage capacity, which has been published in Hertz ${ }^{1}$ and quenched qualities, which will be treated separately.

It has been of importance to ensure a coherent theory for design of fire-exposed structures and design for other load cases such as, for example ultimate load at $20^{\circ} \mathrm{C}$. This means that the materials data and the design methods should also be applicable for a traditional cold design if the fire varies towards no fire and values for $20^{\circ} \mathrm{C}$ are applied. Also the residual properties after a fire are of importance for finding the minimum load bearing capacity for fully developed fires, and for reusing fire damaged constructions. And since these calculations are often made for existing constructions, old qualities of reinforcement are also considered to be of interest.

If a test programme is made for the properties of an actual steel, precise materials data can be applied for the fire safety design. This is a good possibility for prefabricated constructions, where a factory uses the same reinforcement for a large part of the production. But for a consulting engineer designing a construction to be built in a few copies it is seldom realistic to refer to a test programme, unless the steel producers have performed it in advance and it is possible to prescribe a specific steel.

It is therefore the intention of this paper to present idealised materials data that can be used for a calculation of the loadbearing capacity on the safe side, if only the main data of the actual steel are known or prescribed.

The materials data applied are partly collected, derived and recalculated from the literature as reported for example in $\mathrm{Hertz}^{2}$ and partly found by materials tests in the author's laboratory or derived from full-scale tests. Some data are provided by other colleagues participating in the project team TC250/SC2/PT10 writing the fire chapter of the CEN code for concrete constructions ${ }^{3}$.

Further research has been made in order to find coherent explanations for the values of the raw data found, and a single formula is derived by means of which any reduction of the material properties can be described, which can facilitate both the communication of reduction curves and calculations and the development of calculation programs for fire exposed constructions. 


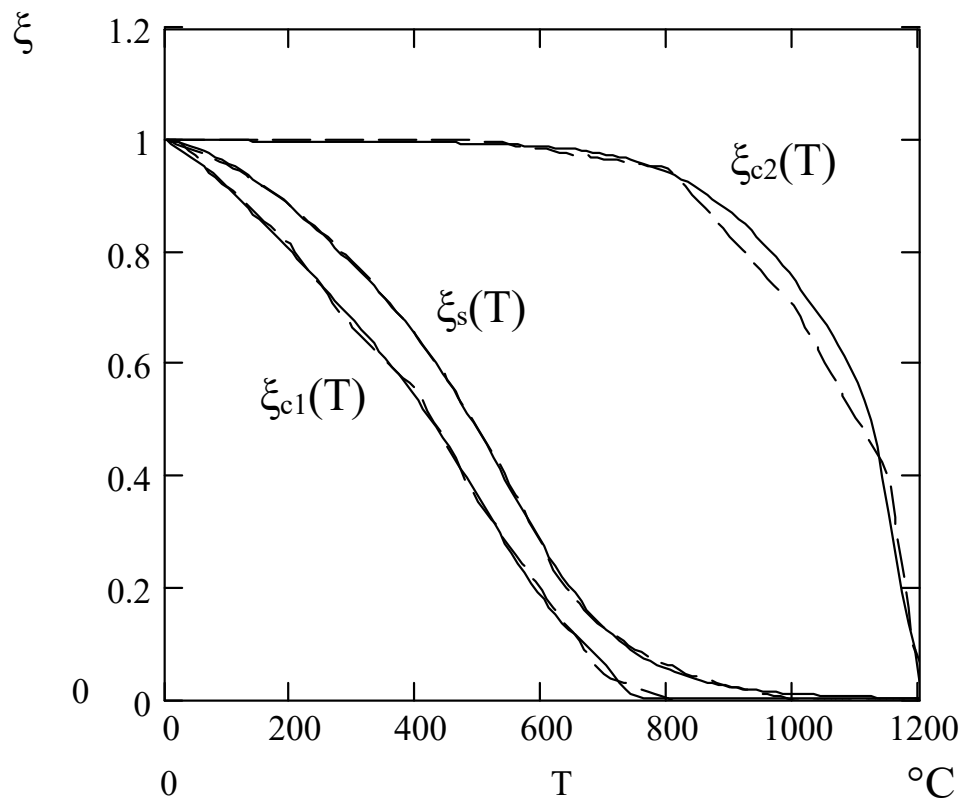

Fig. 1. Some S-curves for steel and concrete compared with test data (dashed)

\section{A general expression for deterioration curves}

Almost any material is damaged by heat so that the damage can be described by an S-shaped curve, which in some cases tends to be a straight line and in other cases show a sudden damage at a certain temperature.

The author has found that these curve shapes for the purpose of design can be expressed by the very same mathematical expression, given as

$$
\xi(\mathrm{T})=\mathrm{k}+\frac{1-\mathrm{k}}{1+\frac{\mathrm{T}}{\mathrm{T}_{1}}+\left(\frac{\mathrm{T}}{\mathrm{T}_{2}}\right)^{2}+\left(\frac{\mathrm{T}}{\mathrm{T}_{8}}\right)^{8}+\left(\frac{\mathrm{T}}{\mathrm{T}_{64}}\right)^{64}}
$$

Where the Greek letter $\xi$ means a ratio between a material property such as the tensile strength at a given temperature $\mathrm{T}^{\circ} \mathrm{C}$ and the same property at $20^{\circ} \mathrm{C} . \mathrm{T}_{1}$ to $\mathrm{T}_{64}$ are parameters with the unit ${ }^{\circ} \mathrm{C}$ describing the curve and $\mathrm{k}$ the ratio between the minimum and the maximum value of the property, which is often 0 except for residual properties after a fire exposure.

An S-shaped curve is obtained by using ratios between the variable $\mathrm{T}$ and fixed parameters in the denominator. A fixed value determines at which temperature the ratio reduces the entire expression, and the power of a ratio determines how steep the reduction will be. Compared to other possible S-shaped curves given by, for example logarithmic or tangential expressions, this is found to give the best fit for the extreme curves which can be expected describing reductions of material properties.

In Fig. 1 the flexibility of the expression is demonstrated. 
Magazine of Concrete Research

The almost straight line $\xi_{\mathrm{cl}}(\mathrm{T})$ is given by $\left(\mathrm{k}, \mathrm{T}_{1}, \mathrm{~T}_{2}, \mathrm{~T}_{8}, \mathrm{~T}_{64}\right)=(0,1500,580,520,690)$ and represents the reduction of compressive strength of a concrete based on Scandinavian sea gravel which has been heated rapidly. This curve models test results found by the author for the same property $\xi_{\text {cltest }}(\mathrm{T})$ published in $\mathrm{Hertz}^{4}$, where the specimens were heated $10^{\circ} \mathrm{C}$ per minute with a uniform temperature distribution obtained by means of microwave power.

The curve $\xi_{\mathrm{c} 2}(\mathrm{~T})$ given by $\left(\mathrm{k}, \mathrm{T}_{1}, \mathrm{~T}_{2}, \mathrm{~T}_{8}, \mathrm{~T}_{64}\right)=(0,100000,100000,1150,1150)$ represents the reduction of the compressive strength of a Russian fire-resistant concrete (Nekrasov and Tarasova ${ }^{5}$ ). Test data are shown as $\xi_{\text {c2test }}(\mathrm{T})$. This curve is scarcely reduced for temperatures less than $800^{\circ} \mathrm{C}$, but is suddenly reduced to none at $1150^{\circ} \mathrm{C}$, where the material melts.

The S-curve $\xi_{\mathrm{s}}(\mathrm{T})$ represents the reduction of yield strength or $0.2 \%$ strength of a mild or a hot-rolled reinforcing steel, which is compared with the best idealized curve $\xi_{\mathrm{s} 02}(\mathrm{~T})$ for this property so far given in $\mathrm{ECCS}^{6}$ and applied for example in the Danish code for steel constructions from $1983^{7}$ and corresponding slightly on the safe side to most test results of this property ${ }^{8-10}$.

The curve is given by the expression

$$
\begin{aligned}
& \xi_{\mathrm{s} 02}(\mathrm{~T})=\left[1+\frac{\mathrm{T}}{767 \cdot \ln \left(\frac{\mathrm{T}}{1750}\right)}\right] \text { for } 0^{\circ} \mathrm{C}<\mathrm{T} \leq 600^{\circ} \mathrm{C} \\
& \xi_{\mathrm{s} 02}(\mathrm{~T})=\frac{0.108 \cdot(1000-\mathrm{T})}{\mathrm{T}-440} \text { for } 600^{\circ} \mathrm{C}<\mathrm{T} \leq 1000^{\circ} \mathrm{C}
\end{aligned}
$$

It is seen that a new curve $\xi_{\mathrm{s}}(\mathrm{T})$ given by $\left(\mathrm{k}, \mathrm{T}_{1}, \mathrm{~T}_{2}, \mathrm{~T}_{8}, \mathrm{~T}_{64}\right)=(0,6000,620,565,1100)$ gives values practically identical to those from the previous expression.

From these examples it is concluded that the proposed general expression for $\xi(\mathrm{T})$ can model anything from a straight-line reduction over any $\mathrm{S}$ shaped curve to a development where the property is not reduced before a certain temperature is reached. It is also seen that the value always will be in the range within $\mathrm{k}$ and 1 , where $\mathrm{k}$ is often 0 , and that it gives full curves without breaking the expression up into intervals.

Some properties, such as the strength of a fire resistant concrete or a concrete that is not fully hydrated, can increase within the first $100-200^{\circ} \mathrm{C}$, but it is not recommended that an effect like this should be utilised for design, because the increase is often related to the age and condition of the material, whereas a fire safety calculation usually do not take such parameters into account, and because a safe assessment of a temperature development could lead to an unsafe assessment of the loadbearing capacity of the construction. 
Magazine of Concrete Research

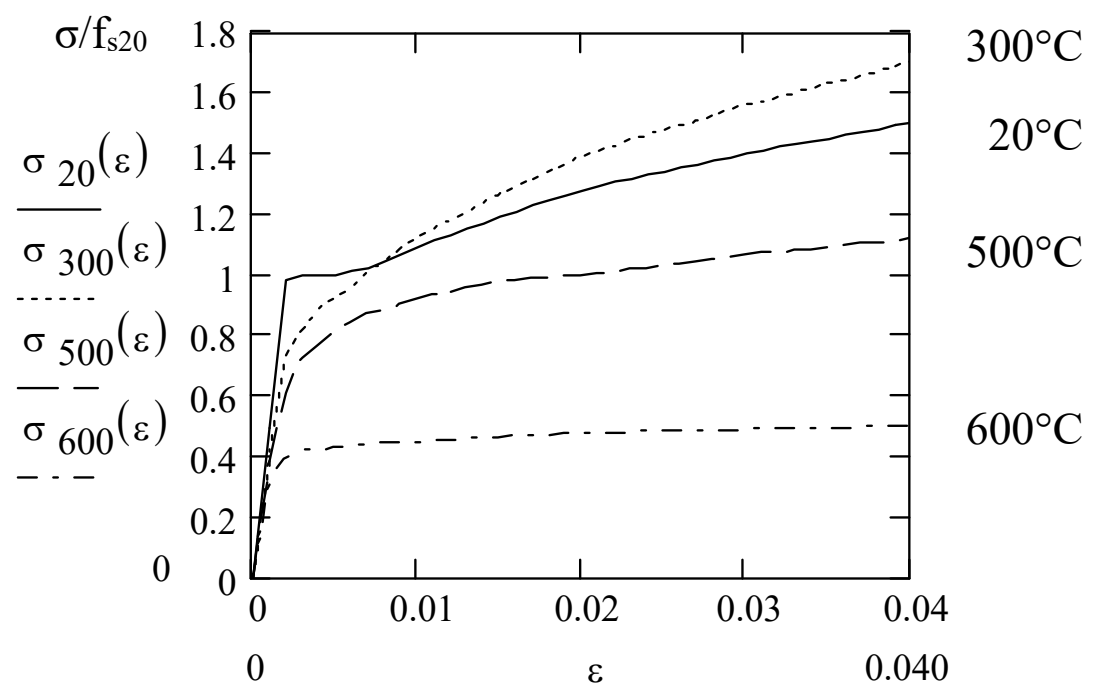

Fig. 2. Stress-strain curves for a mild steel with a $0.2 \%$ proof strength of $253 \mathrm{MPa}$

\section{Properties of fire exposed reinforcement}

Some of the lattice lines of a steel crystal are incomplete. When the crystal is subjected to a shear stress a loose end of a lattice line may combine to a neighbour line, leaving a new loose end, and the line has moved one step. The material yields. Movable irregularities like these are called dislocations, and movement of dislocations can give rise to formation of more dislocations when a crystal is stretched. When sufficiently many are produced they may hinder the movement of each other, increasing the stress necessary for deformation. This is a short explanation of cold-working. If atoms of, for example, carbon and nitrogen are present, or vanadium or niobium are added to the steel, they may serve as anchors for the dislocations, increasing the energy necessary for movement and therefore increasing the yield strength. Nitrogen atoms can move to the dislocations in the time after the steel has been produced, increasing the strength of the material, and the nitrogen content is often reduced to ensure that the material does not become too brittle in time. The carbon content is often reduced to make welding possible. If the temperature is increased, the energy necessary for moving the dislocations is reduced because temperature represents oscillations of the atoms, and the yield stress or the $0.2 \%$ stress will be reduced. Within the first $200-300^{\circ} \mathrm{C}$ an increase in temperature also means that more new dislocations can be produced when a stress is applied, and this effect of cold-working at strains of about $2.0 \%$ or more can lead to an increase of the ultimate strength. This effect is shown in Fig. 2 for a mild steel with a $0.2 \%$ yield strength at $20^{\circ} \mathrm{C}$ of $253 \mathrm{MPa}$ tested by Skinner ${ }^{11}$.

Figure 2 also illustrates that the value of the strain, at which the steel becomes more plastic - that is, the strain of the $0.2 \%$ stress - seems to be almost constant for all temperature levels. The same observation can be made for stress-strain curves of most other reinforcing bars. 
Magazine of Concrete Research

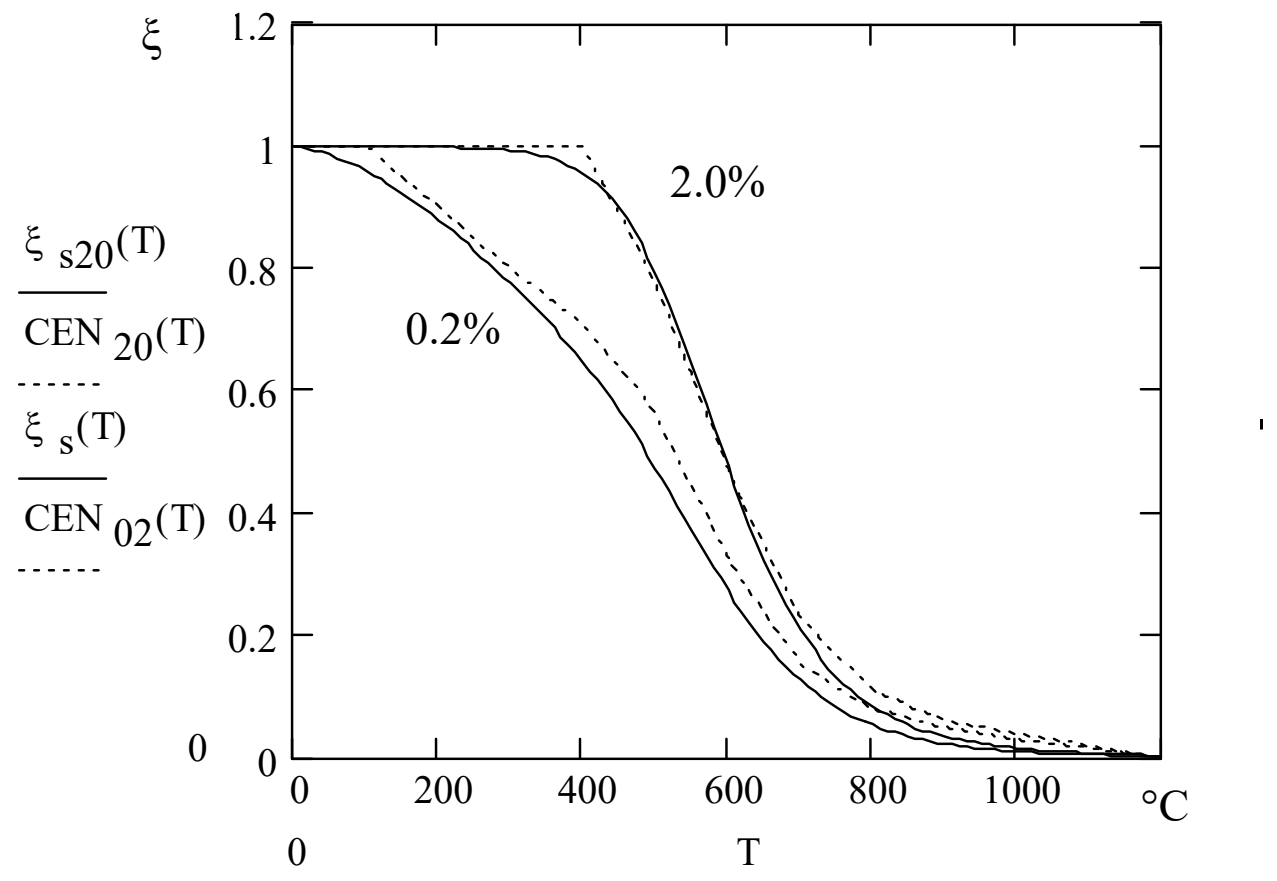

Fig. 3. Reduction of $0.2 \%$ strength and $2.0 \%$ ultimate strength of mild steel and hotrolled bars (solid curves) and the same properties according to CEN (dashed curves).

\section{Hot rolled bars}

The curve $\xi_{\mathrm{s}}(\mathrm{T})$ from Fig. 1 represents, as mentioned, the development of the yield strength or the $0.2 \%$ strength of a mild steel or of hot-rolled bars, where the yield strength has been improved chemically.

In the CEN codes $^{3}$ the upper dotted curve called $\mathrm{CEN}_{20}$ in fig. 3 is tabulated as a strength parameter $\mathrm{f}_{\mathrm{sy}, \theta}$ with the misleading index $\mathrm{y}$. This parameter was at first introduced as the "yield stress" in the drafts for a CEN steel code, and the author and his students ran a project in order to unveil the background for it, because it deviated substantially from the well-documented development of $\xi_{\mathrm{s}}$, which is described above. The curve represents the thermal change of stresses at a strain of no less than $2.0 \%$, where mild steel as shown in Fig. 2 has an increase of the stress level at temperatures within $300^{\circ} \mathrm{C}$. Calculations were made for beams and columns showing that a strain such as this cannot be obtained in the majority of steel constructions before they must be considered to fail owing to large deflections according to the rules from the test standards, or according to common sense. And in compression zones of concrete constructions, reinforcement cannot attain this strain before the concrete is crushed. This was reported to $\mathrm{CEN}^{12}$, and full stress-strain curves were introduced for fireexposed structural steel and reinforcement in the CEN codes, but $f_{\text {sy }, \theta}$ is still a $2.0 \%$ stress and not a yield strength. 
Magazine of Concrete Research

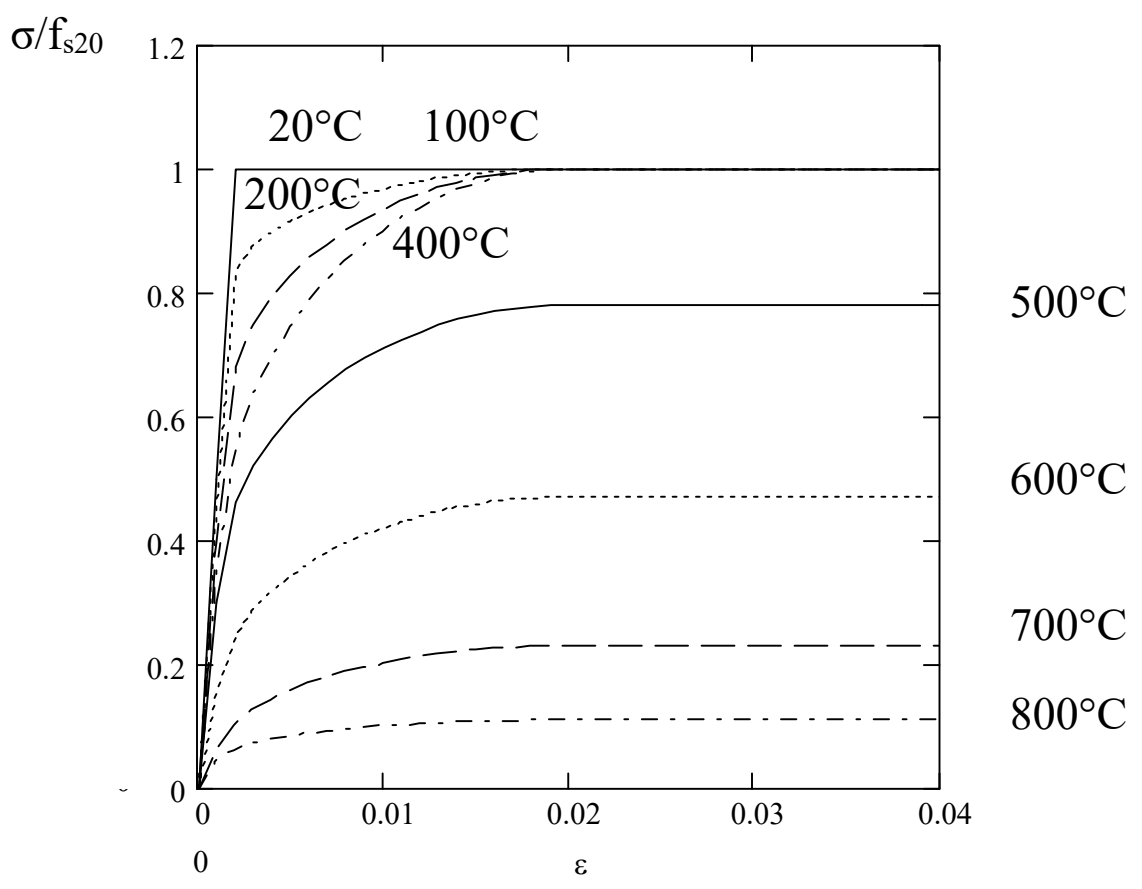

Fig. 4 Idealized stress-strain curves for hot rolled bars according to $\mathrm{CEN}^{3}$

The curve for $2.0 \%$ strain should only be applied if it can be shown that these large strains can be obtained. As mentioned this is seldom possible for steel constructions, but it is possible for some concrete constructions, such as T-shaped cross-sections, where small depths of the compression zones may lead to large strains in the tension reinforcement.

Idealised stress-strain curves from the CEN code are shown in Fig. 4, and calculating the corresponding $0.2 \%$ stresses by solving the complicated equations for the stress strain curves, the resulting curve for the $0.2 \%$ stress is shown as a dotted line $\mathrm{CEN}_{02}$ in Fig. 3. It can be seen that this curve fits reasonably well with the well-documented curve $\xi_{\mathrm{s}}$, which must be recommended to use for nearly all steel constructions and for most concrete constructions.

This means that for hot rolled bars the curve found previously can be applied given by $\left(\mathrm{k}, \mathrm{T}_{1}, \mathrm{~T}_{2}, \mathrm{~T}_{8}, \mathrm{~T}_{64}\right)=(0,6000,620,565,1100)$ for the $0.2 \%$ strength $\xi_{\mathrm{s}}(\mathrm{T})$. And if it can be proved that a strain of $2.0 \%$ or more can be obtained, a curve can be applied for the $2.0 \%$ strength $\xi_{\mathrm{s} 20}(\mathrm{~T})$ given by $\left(\mathrm{k}, \mathrm{T}_{1}, \mathrm{~T}_{2}, \mathrm{~T}_{8}, \mathrm{~T}_{64}\right)=(0,100000,100000,593,100000)$ and shown in Fig. 3.

Experience from tests and fires show that, after a fire, mild steel and hot-rolled bars can be considered to regain their strength, which is obtained through the chemical composition. (If the general formula is used to express this in a program the parameters $\left(\mathrm{k}, \mathrm{T}_{1}, \mathrm{~T}_{2}, \mathrm{~T}_{8}, \mathrm{~T}_{64}\right)=(1,100000,100000,100000,100000)$ are obtained $)$. 
Magazine of Concrete Research

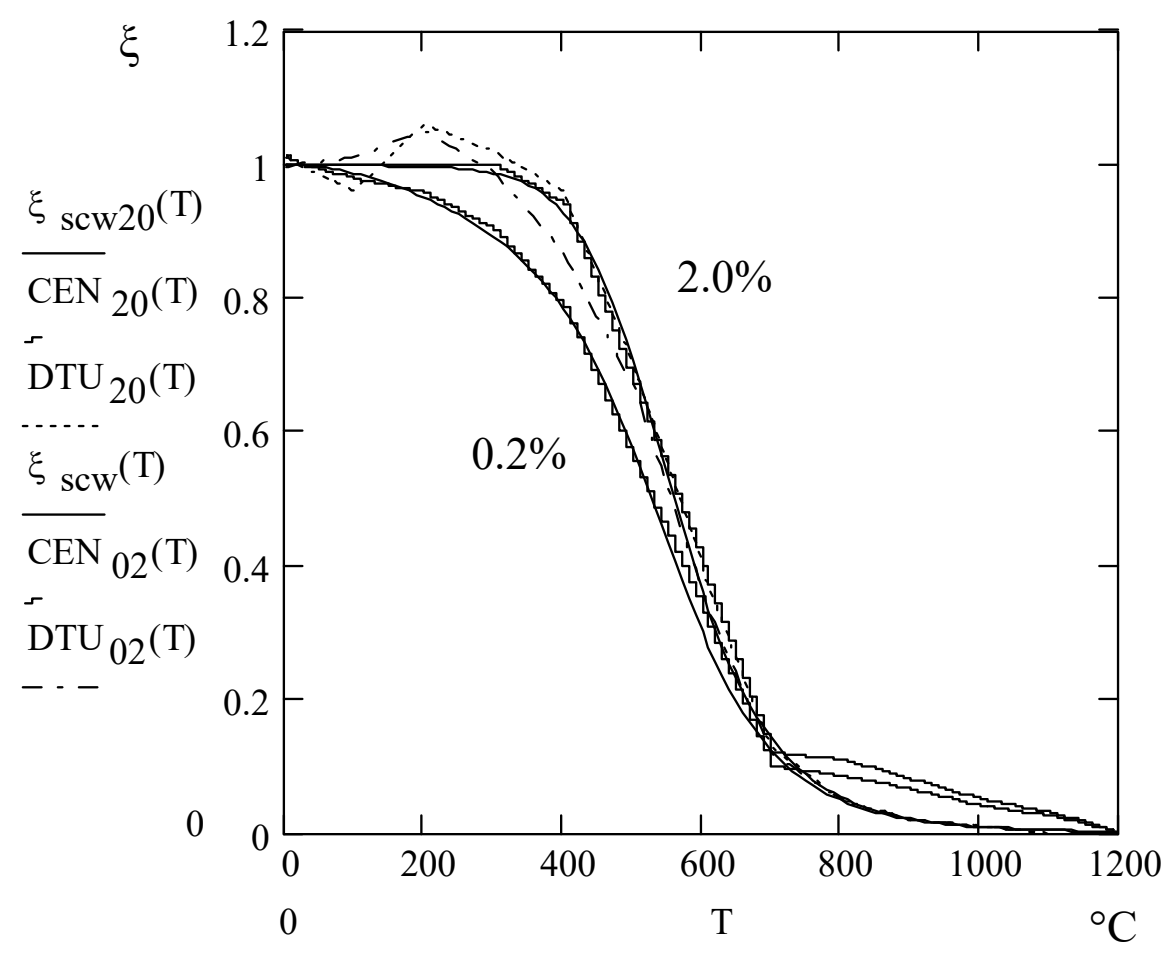

Fig. 5. Reduction of $0.2 \%$ strength and $2.0 \%$ ultimate strength of cold-worked steel of $560 \mathrm{MPa}$

\section{Cold worked bars}

Cold worked reinforcing bars may have an increased $0.2 \%$ strength of about $560 \mathrm{MPa}$ obtained by twisting or stretching or both, or by cold rolling. Twisting creates a chaotic system of dislocations and many sources for formation of new dislocations, which can be utilised by stretching. If a bar is first twisted and then stretched, the steel often becomes so brittle that it is not recommended for structural use. Therefore, steels with the combined effect can be produced by first stretching and then twisting or by a simultaneous process (Caprani and Buchwald ${ }^{13}$ ). Steel like this has been made for many years in Denmark called Danish Tentor, which was stretched 5\% and twisted one turn over a length of 15 times the diameter. Its properties at high temperatures have been measured in the author's laboratory by Petersen and Hansen ${ }^{14}$.

In Fig. 5 the results for the $0.2 \%$ stress and the $2.0 \%$ stress from these tests, supplemented with data from Caprani and Buchwald ${ }^{13}$ are called DTU 02 and DTU 20 respectively. Except for an increase of both strengths between $100^{\circ} \mathrm{C}$ and $300^{\circ} \mathrm{C}$ the test data for these bars are seen to follow the step curves that can be derived from the CEN code for cold-worked bars shown as $\mathrm{CEN}_{02}$ and $\mathrm{CEN}_{20}$ and new idealised curves can be described by the parameters $\left(\mathrm{k}, \mathrm{T}_{1}, \mathrm{~T}_{2}, \mathrm{~T}_{8}, \mathrm{~T}_{64}\right)=(0,100000,900,555,100000)$ for the $0.2 \%$ stress $\xi_{\text {scw }}$ and $\left(\mathrm{k}, \mathrm{T}_{1}, \mathrm{~T}_{2}, \mathrm{~T}_{8}, \mathrm{~T}_{64}\right)=(0,100000,5000,560,100000)$ for the $2.0 \%$ stress $\xi_{\text {scw } 20}$. It seems that these curves can be recommended for cold-worked slack reinforcement of about $550 \mathrm{MPa}$ no matter how it is cold-worked. 
Magazine of Concrete Research

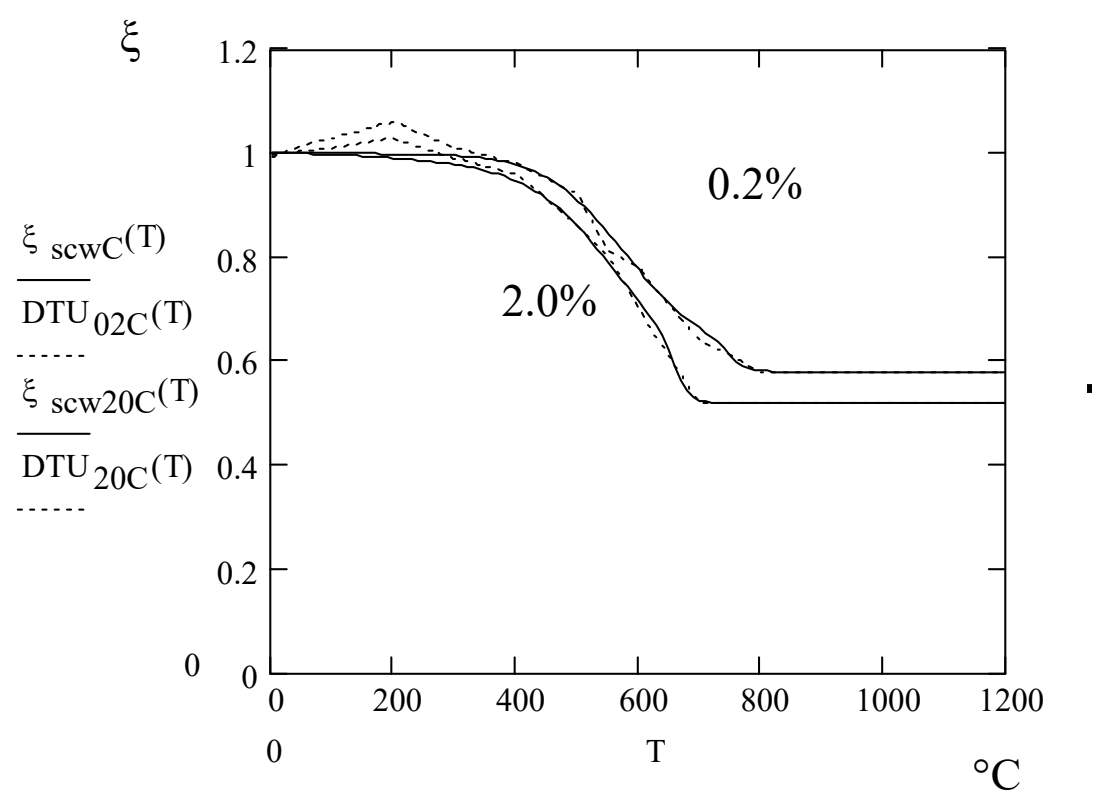

Fig. 6 Residual reduction of $0.2 \%$ strength and $2.0 \%$ ultimate strength of cold worked steel of $560 \mathrm{MPa}$

One explanation of the small reduction of the $0.2 \%$ stress between $100^{\circ} \mathrm{C}$ and $300^{\circ} \mathrm{C}$, and the close position of the two curves, may be that the steel has an initial coldworking strain and dislocation structure, and that it does not take the same strain to reach an improved stress level at these temperatures as it does for hot rolled bars. Above $300^{\circ} \mathrm{C}$ the crystal structure becomes looser, and the borders between the steel grains disappear. From approximately $600^{\circ} \mathrm{C}$, the $0.2 \%$ and $2.0 \%$ stresses of the cold worked bars are reduced to the level of the same properties for hot rolled bars.

In a cold condition after a fire exposure the effect of cold-working is permanently reduced if the temperature has been above $400^{\circ} \mathrm{C}$. And after heating to approximately $800^{\circ} \mathrm{C}$ there is no effect left. This means that the $0.2 \%$ stress, $\xi_{\text {scwC }}$, of a cold worked bar is reduced to the original strength of the steel that it had before it was coldworked - for example $325 \mathrm{MPa}$ in stead of $560 \mathrm{MPa}$ - and the parameter $\mathrm{k}$ is 0.58 (Fig. 6).

The residual reduction $\xi_{\mathrm{scw} 20 \mathrm{C}}$ of the $2,0 \%$ stress seems to be larger in percent mainly because the $2.0 \%$ stress before the fire was larger, and therefore $\mathrm{k}$ is assessed as 0.52 .

The idealized curves can be given by $\left(\mathrm{k}, \mathrm{T}_{1}, \mathrm{~T}_{2}, \mathrm{~T}_{8}, \mathrm{~T}_{64}\right)=(0.58,100000,5000,590,730)$ for the $0.2 \%$ stress, $\xi_{\text {scwC }}$, and $\left(\mathrm{k}, \mathrm{T}_{1}, \mathrm{~T}_{2}, \mathrm{~T}_{8}, \mathrm{~T}_{64}\right)=(0.52,100000,1500,580,650)$ for the $2.0 \%$ stress, $\xi_{\mathrm{scw} 20 \mathrm{C}}$, in a cold condition after a fire. 
Magazine of Concrete Research

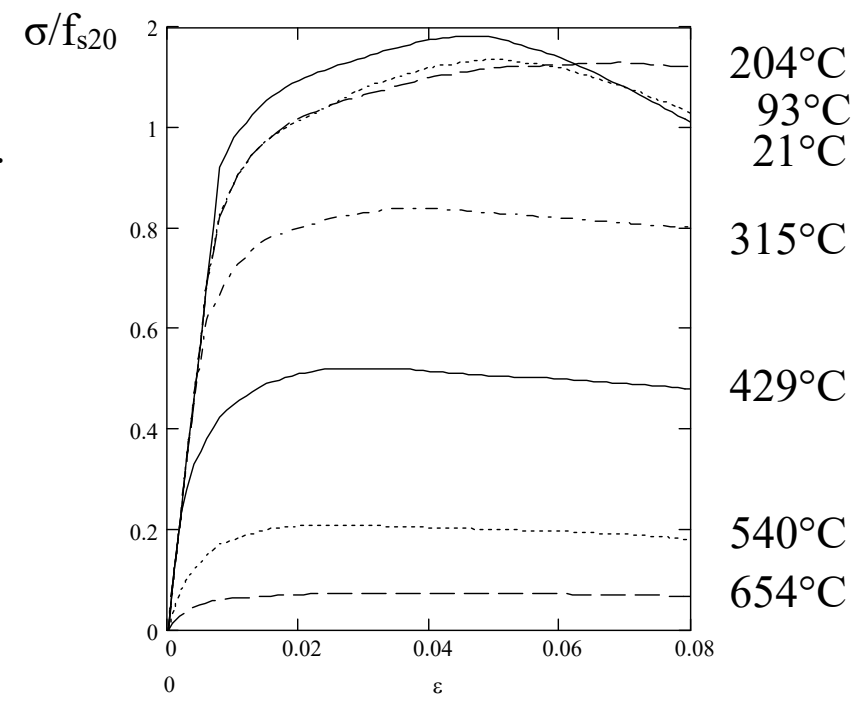

Fig. 7. Stress-strain curves for prestressing wire with a $0.2 \%$ proof strength of $1470 \mathrm{MPa}$ according to Harmathy and Stanzak ${ }^{15}$

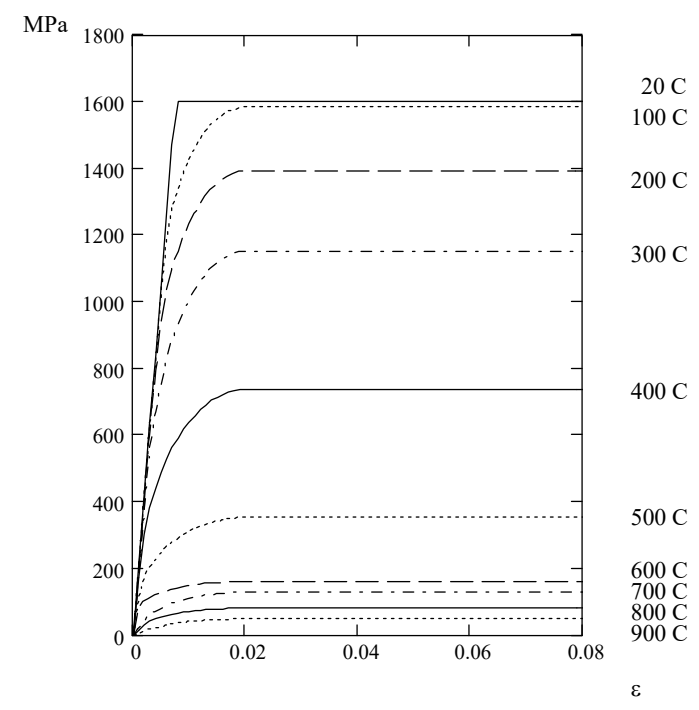

Fig. 8. Stress-strain curves for prestressing wires of $1600 \mathrm{MPa}$ according to $\mathrm{CEN}^{3}$

\section{Cold worked prestressing steel}

Prestressing wires often have $0.2 \%$ strengths of about $1600 \mathrm{MPa}$ obtained by coldworking in tension, and, when they are heated, this effect disappears. The relative drop in $0.2 \%$ strength is considerable because of the high initial strength, and because the extreme effect of the cold-working is reduced rapidly at small temperatures. Stress-strain curves for a wire are given in Fig. 7 based on data from Harmathy and Stanzak $^{15}$, and idealised curves from the CEN $\operatorname{codes}^{3}$ are shown in Fig. 8. A slightly better agreement is obtained comparing the CEN curves with the curves from Ruge and Linnemann ${ }^{8}$ derived from transient tests, where the strain is recorded at different temperatures during heating, with a fixed stress level for each test. This test procedure is more realistic for most fire safety design, and it gives smaller stresses, especially at $200^{\circ} \mathrm{C}$ and $300^{\circ} \mathrm{C}$. A reason for this may be an increased effect of coldworking if the load is applied in a hot condition, but it is also a result of creep giving larger strains for each stress level and thus a smaller stress for a certain strain. Both effects may be found in fire-exposed constructions if the heating rate of the test corresponds with the rate of the fire. Test results ${ }^{16-20}$ support the conclusion that the transient stress strain curves from the CEN code are applicable and safe for most fires. 
Magazine of Concrete Research

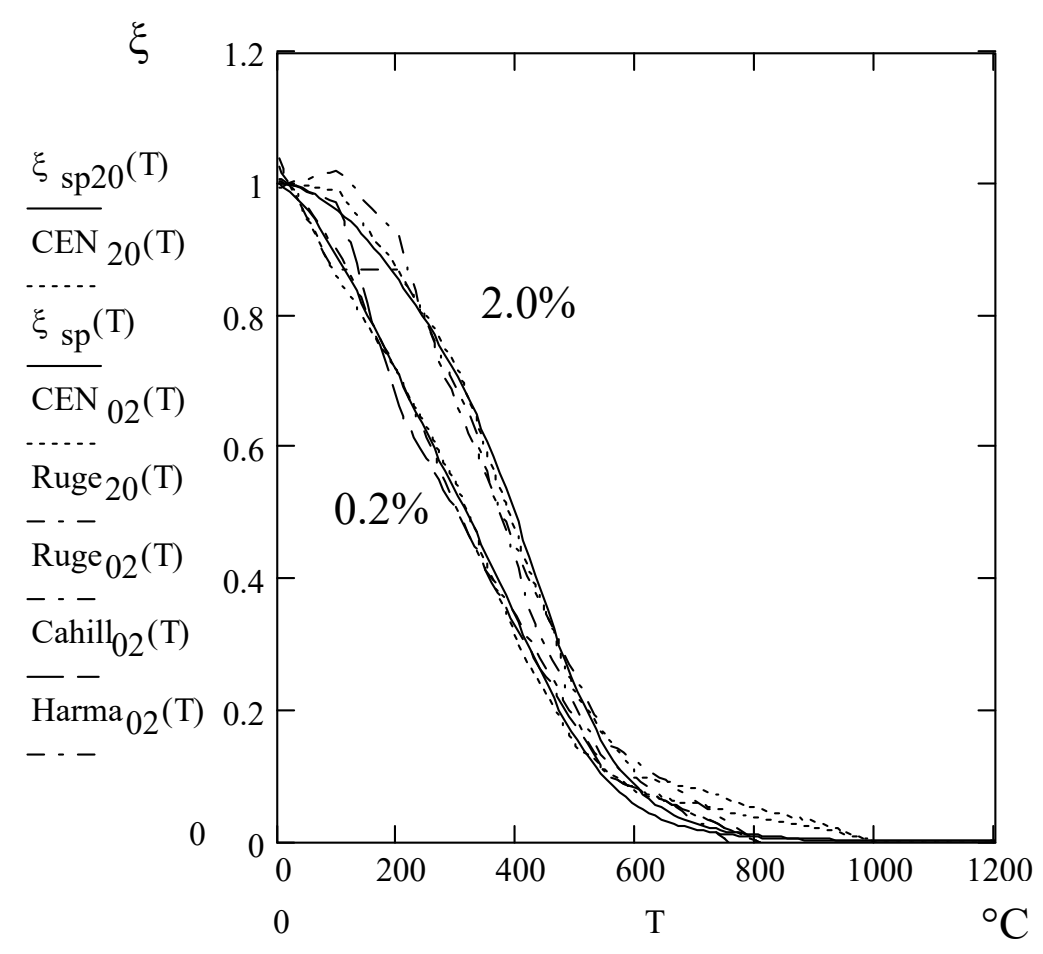

Fig. 9. Reduction of $0.2 \%$ strength and $2.0 \%$ ultimate strength of cold-worked prestressing steels of $1600 \mathrm{MPa}$

Figure 9 shows test data derived from Ruge and Linnemann ${ }^{8}$, Cahill ${ }^{16}$ and Harmathy and Stanzack ${ }^{15}$ and compared to the $2.0 \%$ stress and the $0.2 \%$ stress derived by calculation from the CEN codes (dotted) and new idealized curves (solid) given by $\left(\mathrm{k}, \mathrm{T}_{1}, \mathrm{~T}_{2}, \mathrm{~T}_{8}, \mathrm{~T}_{64}\right)=(0,2000,360,430,100000)$ for the $0.2 \%$ stress, $\xi_{\mathrm{sp}}$, and $\left(\mathrm{k}, \mathrm{T}_{1}, \mathrm{~T}_{2}, \mathrm{~T}_{8}, \mathrm{~T}_{64}\right)=(0,100000,490,450,100000)$ for the $2.0 \%$ stress, $\xi_{\mathrm{sp} 20}$.

Figure 10 shows residual reductions of $0.2 \%$ and $2.0 \%$ stresses for a $1600 \mathrm{MPa}$ colddrawn prestressing steel (dotted), and idealised curves (solid) can be proposed as $\left(\mathrm{k}, \mathrm{T}_{1}, \mathrm{~T}_{2}, \mathrm{~T}_{8}, \mathrm{~T}_{64}\right)=(0.20,100000,750,550,650)$ for the $0.2 \%$ stress, $\xi_{\mathrm{spC}}$, and $\left(\mathrm{k}, \mathrm{T}_{1}, \mathrm{~T}_{2}, \mathrm{~T}_{8}, \mathrm{~T}_{64}\right)=(0.20,100000,950,550,650)$ for the $2.0 \%$ stress, $\xi_{\mathrm{sp} 20 \mathrm{C}}$, in a cold condition after a fire. 
Magazine of Concrete Research

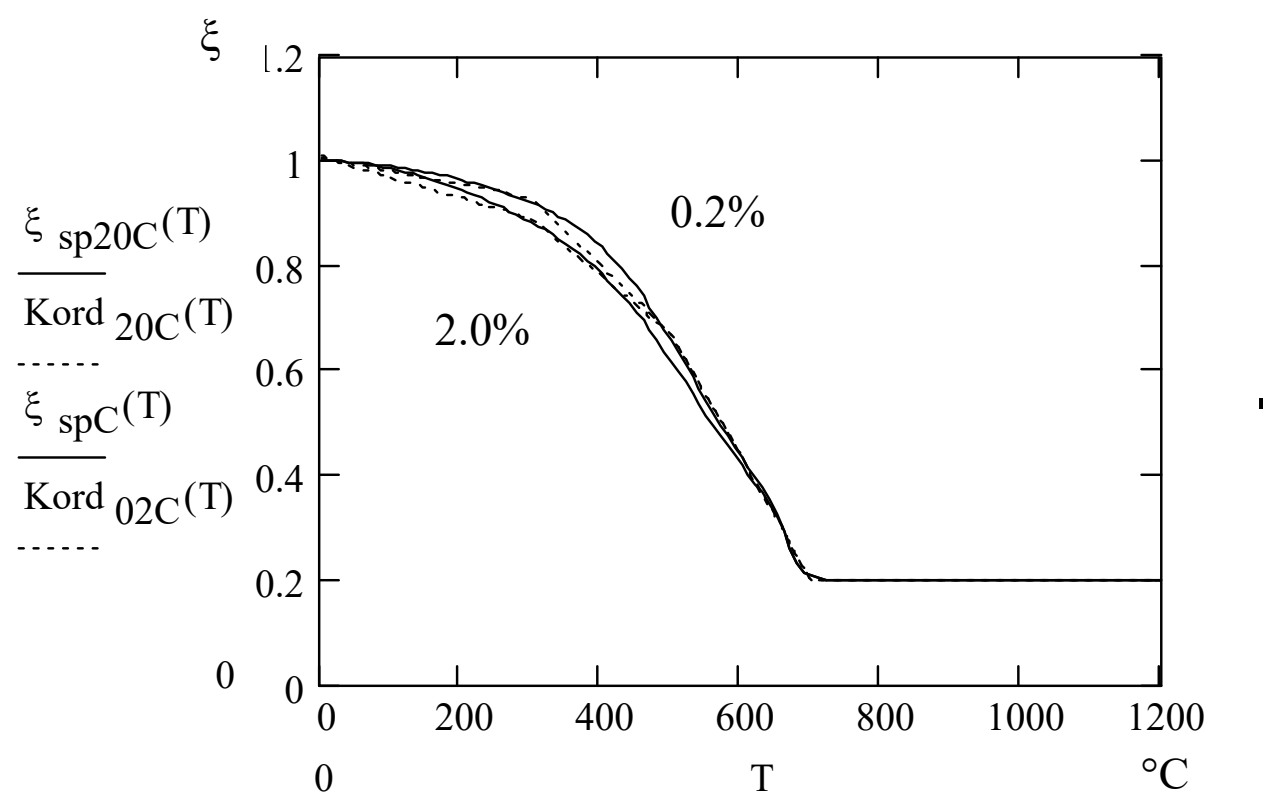

Fig. 10 Residual reductions of $0.2 \%$ strength and $2.0 \%$ ultimate strength of a cold-worked prestressing steel of $1600 \mathrm{MPa}$

\section{Conclusions}

A single formula has been found, by means of which most reductions of mechanical properties for concrete and reinforcement can be given as a function of temperature for fire safety design.

Stresses at a strain of $2.0 \%$ as provided by the CEN codes should be applied only if it can be shown that the reinforcing steel can obtain the corresponding strain. This can seldom be shown for steel structures, but is possible for certain concrete structures like T-shaped cross sections. For other constructions, it is recommended to apply the $0.2 \%$ stress, which often represents a fixed strain of $0.5 \%$

Stresses at strains of $0.2 \%$ and $2.0 \%$ are derived from a number of test series and compared to data derived from the structural codes, and recommended parameters are given for the new expression for the reductions curves. 
Magazine of Concrete Research

\begin{tabular}{|l|c|r|r|r|r|}
\hline & $\mathrm{k}$ & \multicolumn{1}{|c|}{$\mathrm{T}_{1}$} & \multicolumn{1}{c|}{$\mathrm{T}_{2}$} & \multicolumn{1}{c|}{$\mathrm{T}_{8}$} & \multicolumn{1}{c|}{$\mathrm{T}_{64}$} \\
\hline Hot rolled bars 0.2 \% stress & 0.00 & 6000 & 620 & 565 & 1100 \\
\hline Hot rolled bars 2.0 \% stress & 0.00 & 100000 & 100000 & 593 & 100000 \\
\hline Hot rolled bars 0.2 \% residual stress & 1.00 & 100000 & 100000 & 100000 & 100000 \\
\hline Hot rolled bars 2.0 \% residual stress & 1.00 & 100000 & 100000 & 100000 & 100000 \\
\hline Cold worked bars 0.2 \% stress & 0.00 & 100000 & 900 & 555 & 100000 \\
\hline Cold worked bars 2.0\% stress & 0.00 & 100000 & 5000 & 560 & 100000 \\
\hline Cold worked bars 0.2 \% residual stress & 0.58 & 100000 & 5000 & 590 & 730 \\
\hline Cold worked bars 2.0 \% residual stress & 0.52 & 100000 & 1500 & 580 & 650 \\
\hline C-w prestressing steel 0.2\% stress & 0.00 & 2000 & 360 & 430 & 100000 \\
\hline C-w prestressing steel 2.0\% stress & 0.00 & 100000 & 490 & 450 & 100000 \\
\hline C-w prestressing steel 0.2\% residual stress & 0.20 & 100000 & 750 & 550 & 650 \\
\hline C-w prestressing steel 2.0\% residual stress & 0.20 & 100000 & 950 & 550 & 650 \\
\hline
\end{tabular}

Tabel 1. Recommended parameters for design reductions of $0.2 \%$ and $2.0 \%$ stresses of hot-rolled, cold-worked bars and cold-worked prestressing steels during and after fire exposure. 
Magazine of Concrete Research

\section{References}

1. HERTZ K. D. The Anchorage Capacity of Reinforcing Bars at Normal and High Temperatures. Magazine of Concrete Research, 1982, Vol. 34, No. 121, pp. $213-220$.

2. HERTZ K. D. Analyses of Prestressed Concrete Structures Exposed to Fire. Institute of Building Design (now Department of Civil Engineering, Technical University of Denmark), 1985, Report 174. 152 p.

3. Secretariat of CEN/TC 250/SC 2. Design of Concrete Structures: General Rules, Structural Fire Design. CEN 1994 and 2002, ENV 1992-1-2.

4. HERTZ K. D.: Residual Properties of Concrete Heated Rapidly. American Concrete Institute, Detroit 1986, ACI Special Publication SP-92, pp. 143-152.

5. НЕКРАСОВ К. Д. ТАРАСОВА А. П. Жаростойкий бетон на портландцементе. Издательство литературы по строительству, Москва 1969. (NEKRASOV K. D. and TARASOVA A. P. Heat resistant concrete of Portland cement. Structural Literature Publisher, Moscow 1969.)

6. European Convention for Constructional Steelwork (ECCS), Committee 3. European Recommendations for the Design of Steel Structures Exposed to the Standard Fire. Final Draft April 1979, published 1981.

7. Danish Standardisation Organisation. Danish Code of Practice for Steel Constructions, 1983, DS412, $2^{\text {nd }}$ edn . 
Magazine of Concrete Research

8. RUGE J. and LINNEMANN R. Festigkeits- und Verformungsverhalten von Bau-, Beton- und Spannstählen bei hohen Temperaturen.

Technische Universität Braunschweig, 1983, Sonderforschungsbereich 148, B4, pp. 159-212.

9. ANDERBERG Y. Armeringsståls mekaniska egenskaper vid höga temperaturer (Mechanical properties of reinforcement at high temperatures). Department for building constructions, Technical university of Lund, 1978; or Fire Safety Journal, 1988, Vol. 13, pp. 17-26.

10. KIRBY B. R. and PRESTON R. R. High Temperature Properties of Hot Rolled, Structural Steels for use in Fire Engineering Design Studies. British Steel Coorporation, 1987. 17p; or Fire Safety Journal, 1988, Vol. 13, pp. 27-37.

11. SKINNER D. H. Measurement of High Temperature Properties of Steel. Melburne Research Laboratories, May 1972, MRL 6/10.

12. HERTZ K. D. Review of Differences of Steel related Properties between Proposals of European Structural Codes. Letter to CEN/TC250. April 1993. Department of Civil engineering, Technical University of Denmark, 2004, Report 099.

13. CAPRANI W. E. and BUCHWALD V.: Tentorstål, Glimt af Metallurgiens udvikling i Danmark (Glimpse of the development of metallurgy in Denmark), Danish Society for Metallurgy, Copenhagen 1975, pp. 165-187.

14. SCHOU PETERSEN B. and HANSEN P. Tentorståls brandtekniske egenskaber. (Properties of fire exposed tentor steel).

M.Sc. project, Institute of Building Design (now Department of Civil Engineering, Technical University of Denmark). 1977.

15. HARMATHY T. Z. and STANZAK W. W. Elevated Temperatures Tensile and Creep Properties of Some Structural and Prestressing Steels. National Research Council of Canada, Division of Building Research, Ottawa 1970, Research Paper No. 424 NCR 11163.

16. CAHILL T. The Behaviour of Prestressing Wire at Elevated Temperatures. Proceedings of a Symposium on Fire Resistance of Prestressed Concrete, Braunschweig, 1965. 
Magazine of Concrete Research

17. DANNENBERG J. Festigheitsuntersuchungen Bewehrungsstahls bis $600^{\circ} \mathrm{C}$. Deutscher Ausschuss für Stahlbeton, Heft 132. Wilhelm Ernst und Sohn. Berlin, 1959.

18. VOVES B. Behaviour of Prestressed Concrete Structures during Fire. Czechoslovakian Technical University, Prague, 1978.

19. KORDINA K. Das Verhalten von Stahlbeton- und Spannbetonbauteilen unter Feuerangriff. Heft 2. Institut für Baustoffkunde und Stahlbetonbau der Technischen Hochschule Braunschweig, February 1963.

20. ANDERBERG Y. Behaviour of Steel at High Temperatures. Report of RILEM Committee 44-PHT, February 1983. 